\title{
Practice of Taking Over the Power of The Board of Directors with Notary Deed at PT. Nunut Agung Perkasa in Central Tapanuli District, North Sumatra Province
}

\author{
Lamtiur Romani Hutabarat ${ }^{1}$, Azharuddin $^{2}$, Willytanjaya $^{3}$, Yusriando ${ }^{4}$, Mulyadi $^{5}$ \\ \{lamtiuromani1990@gmail.com, azharuddin@unprimdn.ac.id², willytanjaya@unprimdn.ac.id², \\ mulyadiunpri@gmail.com5\} \\ Universitas Prima Indonesia
}

\begin{abstract}
Limited Liability Company was established based on an agreement, an association of parties who agree to establish a business entity in the form of a limited liability company. The established of a Limited Liability Company cannot be separated from the conditions for the validity of an agreement the company's assets are separated from the personal assets of the company owners so that they have their own assets. This writing aims analyzing the practice of taking over the power of directors at PT. Nunut Agung Perkasa with a notary deed. Analyze due to the law of taking over the power of the board of directors at PT. Nunut Agung Perkasa. Analyzing the responsibilities of the board of directors for irregularities in connection with the power of the board of directors. The approach method used in this research was juridical empirical. Notary deed was an agreement between the parties that binds them.
\end{abstract}

Keywords: Objection; limited liability company, agreement, notary deed

\section{Introduction}

The term company refers to the method of determining capital, which was divided into shares, while the term limited refers to the limit of responsibility of the shareholders, which was only limited to the nominal number of shares owned. Limited Liability Company was a legal entity. Limited Liability Company as a legal entity, this means that the Limited Liability Company was a legal subject, where the Limited Liability Company was an entity that can be burdened with rights and obligations like humans in general. Legal entity means a person who was deliberately created by law. As a legal entity, a Limited Liability Company has its own separate assets from the assets of its management.

The exwastence of a Limited Liability Company or hereinafter referred to as PT, in Indonesia was regulated in Law Number 40 of 2007 UUPT. Where in article 1 number 1 of the Company Law it was explained that PT was a legal entity or it can be called a recht persoon which was a capital alliance which was establish based on an agreement and carries out business activities with authorized capital which was entirely divided into shares by fulfilling the requirements set out in the Company Law and its implementing regulations. . because its status as a legal entity of a PT was equated as a human being who has the characterwastics, personality and will that are formed by the equipment, in order to be able to 
carry out its activities, it was necessary to have equipment called the organ of the company which conswasts of three types, namely the GMS, the Board of Directors and the Commwassioner. To establwash a PT, it was not enough to use an official deed, only with the agreement of the parties agreeing to establwash a PT, a deed made by a Notary which includes the other name of the Limited Liability Company, capital, line of business, company address, and others. Thwas deed must be approved by the Minwaster of Law and Human Rights of the Republic of Indonesia, formerly the Minwaster of Justice.

To obtain permwassion from the Minwaster of Justice and Human Rights, must meet the following requirements:

1. Limited liability companies do not conflict with public order and morals.

2. The deed of establwashment meets the requirements stipulated by law.

Based on the background of the above problems, the author draws the title of this Theswas, namely: to find out the process of transferring the power of directors to a limited liability company with a notary deed.

b. Formulation of the problem

Based on this description, the problem formulations in this paper are.

1. How was the practice of taking over the power of the board of directors at PT. Nunut Agung Perkasa with a notary deed?

2. What was the legal effect of taking over the power of directors at PT. Nunut Agung Perkasa?

3. What was the responsibility of the directors for irregularities in connection with the power of the board of directors?

\section{Research Methods}

The objectives achieved in writing this theswas are divided into two, namely general goals and specific goals.

1. General purpose

The general objectives of this research are academic objectives, namely:

a. Fulfilling the task and completing part of the requirements to achieve the Master's Degree in Notariat Universitas Prima Indonesia.

b. Adding insight and knowledge to the author in Law, especially legal wassues related to the notariat.

c. Apply legal knowledge obtained during the study period and develop and make practical juridical analyswas.

2. Special purpose

The specific objectives of this theswas are:

a. To find out and analyze the practice of taking over the power of the board of directors at PT Nunut Agung Perkasa with a notary deed.

b. To find out and analyze the legal consequences of taking over the power of the board of directors at PT Nunut Agung Perkasa.

c. To find out and analyze the responsibilities of the directors for irregularities in connection with the power of the board of directors. 


\subsection{Benefits of research}

The benefits that can be expected from writing this theswas are:

1. Theoretically, the results of this research are expected to contribute to the development of legal science, especially in the field of notary law, which will benefit the community in general and for academics and legal practitioners, especially notaries, which it will make practically. The results of this study are expected to provide a contribution of thought that can be used as consideration for the institutions involved in it and the community in making further decwasions.

2. In practical terms, the results of this study are expected to provide a contribution of thought that can be used as material for consideration for the institutions involved in it and the community in making further decwasions, in this case to find out legal protection for parties who have tied themselves in the agreement of the power of attorney and the recipient of the power of attorney. directors.

3. For academics, hopefully this research can be used as a baswas for conducting further research on legal protection for parties who will bind themselves to the agreement to transfer the power of the board of directors.

\subsection{Theory and Conceptual Framework}

\section{Theoretical framework}

The theory in this study uses the theoretical approach of "Legal Protection" as a grand theory supported by the legal theory of "legal certainty." As a middle theory. According to Fitzgerald, he explained Salmon's legal protection theory that law aims to integrate and coordinate various interests in society because in a traffic of interests, protection of certain interests can only be done by limiting various interests on the other side [1]. The interest of law was to take care of human rights and interests, so that the law has the highest authority to determine human interests that need to be regulated and protected. The theoretical framework was described as follows:

a. Legal Protection Theory.

b. Legal certainty theory.

\section{Conception}

In legal research, the conceptual framework was obtained from statutory regulations or through efforts to form legal definitions. If the conceptual framework was taken from certain laws and regulations, then usually the conceptual framework also formulates certain definitions, which can be used as operational guidelines in the process of data collection, processing, analyswas and construction.

a. PT Was an abbreviation of a limited liability company, which was a form of company in which the capital was divided into shares, and the responsibility of investors for the amount of capital owned.

b. The Board of Directors was a corporate organ that was fully responsible for the management of the company for the interests and objectives of the company and represents the company both inside and outside the court in accordance with the provwasions of the Articles of Association.

c. Deed was a certificate of evidence containing information, confession, decwasions regarding legal events made and legalized by official officials and deliberately made to be used as evidence about events of actions, agreements or decrees and signed. Notary Deed in accordance with Article 1 number 7 of the Law on the Position of Notary (UUJN) number 2 of 2014, that the Notary Deed, hereinafter referred to as deed, was an 
authentic deed made by or before a Notary according to the forms and procedures stipulated in this law.

\subsection{Research methods}

Based on this, the method that must be used in research must be precwase so that it can be a systematic and directed reference in producing a new argument, theory or concept as a preteswas in solving a problem. The empirical juridical legal research method has several contents, namely the type of research, the type of problem approach, the type of legal material, the procedure for collecting legal materials and processing and analyswas of legal materials. In line with the description above, the research method used as a guideline in writing this theswas was as written in the description below.

1. Types and Nature of Research

There are several approaches in legal research there are several approaches. With this approach, research will obtain information from various aspects of the wassue being tried to find answers. In this theswas the approach taken by the author was as follows:

a. Approach to the Law

b. Conceptual Approach

2. Source of Legal Material

The secondary data source comes from library research. For secondary data sources in the form of library research conducted on various sources of legal materials which can be classified into 3 (three) types, namely:

a. Primary legal material (primary resource or authoritative records), in the form of law, a number of statements or facts that are directly obtained through field research.

The primary legal materials used by the author in writing this theswas include:

- Law No. 40 of 2007 concerning Limited Liability Companies.

- Notary Position Law No. 2 of 2014.

- Code of Civil law.

- Presidential Regulation No. 54 of 2010 concerning the Procurement of Goods and Services.

b. Secondary Legal Materials.

c. Tertiary legal materials (tertary resources), in the form of legal materials that can provide guidance and clarity on primary and secondary legal materials such as those from dictionaries.

3. Data collection technique

To obtain the necessary data, the author uses the following data collection techniques:

a. Observation was a systematic observation that the author does by directly vwasiting the research location.

b. The interview was a way to collect data by conducting interviews with direct questions and answers.

c. Literature study was carried out by searching, taking inventory and studying statutory regulations and other primary data relating to the problem under study.

4. Data analyswas

Analyswas of legal materials was a method used by the author in determining answers to the problems dwascussed. To be able to analyze the material that has been obtained, the author must use several steps in legal research in order to determine the right results to answer the exwasting problem. The data obtained in further research was described in accordance with the subject matter which was studied in a qualitative juridical manner, namely data reduction. 


\section{Results and Discussion}

\subsection{How Is He Practice of Taking Over the Power of The Board of Directors at Pt. Nunut Agung Perkasa Follow with A Notarial Deed}

\section{Overview of Limited Liability Companies}

As a legal entity, a Limited Liability Company must have the aims and objectives and activities of the company as stated in the articles of association. The company must have goals and objectives as well as business activities that do not conflict with the provwasions of laws and regulations, public order, and / or morality, as stipulated in Article 2 of Company Law No. 40 of 2007. In the context of legal prowess or being able to act in this legal traffic, this was one of the main differences between a human being and a legal entity, in this case a limited liability company. If humans in general can do any legal action, even at the same time, then for the company that was not the case. The company can only do not more than what has been stipulated in its articles of association.

In fact, the purpose of a limited liability company was to seek profit, although this was not expressly stated by the Law No. 40 of 2007. The objective of shareholders to deposit their capital was none other than expecting to get a share of the company's profit, namely dividends. However, article 2 jo. Article 18 Company Law No. 40/2007 only states that a company must have a purpose and objective as well as business activities, which must be stated in its articles of association, and must not conflict with statutory provwasions, public order, or morals. The author has never found article 3 of a company's articles of association which explicitly mentions this profit-seeking.

Anything related to a legal entity, for example in establwashing a PT, must use an official deed, namely a deed made by a notary in which the other name of the limited liability company, capital, line of business, company address was included. Thwas deed must be approved by the Minwaster of Law and Human Rights of the Republic of Indonesia, first it must be approved by the Minwaster of Justice of the Republic of Indonesia. To obtain permwassion from the Minwaster of Justice and Human Rights, must meet the following requirements:

a. Limited liability companies do not conflict with public order and morals.

b. The deed of establwashment meets the requirements stipulated by law.

c. The minimum wassued and paid-up capital was $25 \%$ of the authorized capital.

The incorporation deed of a Limited Liability Company requires a notary deed because such deed was an authentic deed. In the law of proof, an authentic deed was seen as a binding and perfect evidence. Thwas means that what was written in the deed must be trusted and does not require additional evidence.

\section{Practice of Acquwasition of the Board of Directors with a Notary Deed}

Each agreement in order to be valid as a binding agreement as law for those who make it. The agreement must be made based on valid terms. Notary deed was an agreement between the parties that binds them, therefore all the conditions of an agreement must be fulfilled.

According to the provwasions of article 1320 of the Civil Code, in order for an agreement to be valid as a legal agreement, there are the following conditions:

1. Their agreement was binding on him.

2. The ability to make an engagement.

3. A certain subject matter.

4. A cause that was lawful. 
There are five ways in which the statement of the will occurs, namely: [2]

1. Perfect and written language

2. Perfect and spoken language.

3. Language that was not perfect as long as it can be accepted by the opposing party, because in reality someone often communicates in a language that was not perfect but it was understood by the other party.

4. That the original conditions can be accepted by the opposing party.

5. Silent or silent but as long as the opposing party understands or accepts it.

In connection with the terms of the agreement, those who bind themselves, there are several factors that can cause defects in the agreement which are stated in Article 1321 of the Civil Code which reads: "There was no valid agreement if the agreement was given due to an error, or was obtained by coercion or fraud. "[3]. Defect of will or dwasability of agreement can occur because of things including;

1. Mwastakenly or get lost.

2. Coercion.

3. Fraud

4. Abuse of circumstances.

According to Mariam Darus Badrulzaman, what was meant by coercion was: physical violence or threats (to reveal secrets) with something that was allowed by law which creates fear in a person so that he makes an agreement [4]. Meanwhile, according to Subekti, coercion referred to as spiritual coercion or mental compulsion (psysicwas), so it was not compulsion of the body (physical). Coercion occurs when the coerced party has no other choice but to agree to the agreement and the coercion may be carried out by a third party [5].

People who are not capable of making agreements based on these conditions are:

1. Immature people.

2. People who are put under interdiction.

3. Married women.

The Civil Code also places married women as people who are incapable of making an agreement. Things that show married women are not capable of acting in law, for example Article 108 paragraph (2) of the Civil Code reads: "A wife, so that she has been empowered by her husband, to make a deed, or to lift an agreement even, but she was not because it has the right, to receive a payment, or to pay off it, without express permwassion from her husband".

When making notary deeds, whether made before or by Notary officials, the parties are legal entities, namely entities or entities formed by law, often face the problem of whether the party representing the legal entity was truly authorized or not in taking action. law in the deed. In this case, the notary must be careful and careful to see the authority of an actor. If not, then the deed he has drawn up has the potential to become an underhand deed which could harm the third party because the party acting in the deed was not authorized or legal.

There are 3 (three) requirements to become a tapper:

First, with one's own presence, that was, the party acting and for its own benefit. Second, through or through the power of attorney, either verbally or in writing. Although it was permwassible to do it orally, in practice usually the power was given in writing, whether made under the hands, purely or by legalization of a notary, or with a notarial power of attorney. 
Third, the party acting in hwas position or position, for example a director who appears as the legal representative of a Limited Liability Company. According to the theory, the wassue of the authority to act in a deed actually includes 2 things, namely whether the party who was the actor was legally competent, for example whether he was an adult or not and whether the actor has the right or was empowered to be empowered to take certain legal actions.

Given that legally with proof of notary deed, the director's power of attorney was valid or legal to carry out legal actions authorized by the Authorized Author, then after all the conditions for carrying out the agreement have been fulfilled, the parties go to the Notary to make an agreement binding as did Mr. MARTIN TOBING as Director Main PT. NUNUT AGUNG PERKASA, has given special power to Mr. BERRY SIANTURI based on the power of attorney of the board of directors No. 20 (twenty) dated 6 November 2006, drawn up before the Notary MEGAWATI NASUTION, SH Where in the power of attorney for the board of directors Number 20 (twenty) dated 6 November 2006 states, among other things, that for and on behalf of PT. Nunut Agung Perkasa, BERRY SIANTURI aka BERRY SIANTURI carries out and works and then takes all necessary actions to ensure the smooth progress of the construction of the Fwash Landing Base Facilities and Infrastructure in Labuhan Angin, including receiving all the piece rate payments for the work. After the parties agree on the binding agreement, the Notary wassues a power of attorney with the following description:

---- Tuan Engineer UNEDO MARTIN TOBING born in Sibolga on 17 (seventeen) March 1972 (one thousand nine hundred and seventy two), Indonesian citizen, self-employed, residing in Central Tapanuli Regency, Sibolga Dwastrict, Sibuluan III Village, Padang Sidempuan Street:

--- according to hwas statement in this matter he was acting in hwas position as Director of - and thus for and on behalf of a limited liability company "PT. NUNUT AGUNG PERKASA ", having its domicile in Central Tapanuli Regency, which was establish by deed dated 17 (seventeen) March 2004 (two thousand and four) number 08, and has been amended by deed number 31, dated 29 (twenty nine) May 2006 (two thousand and six), both of which were made before the Notary who made this deed, and which articles of association were approved by the Minwaster of Law and Human Rights of the Republic of Indonesia dated 14 (fourteen) August 2006 (two thousand and six) number C-23700HT, 01.01.TH.2006 , and according to the acknowledgment of the said articles of association that has never been amended, and to take legal action in this deed,-

--- The party acting in hwas position as mentioned above hereby grants power of attorney to:

--- Mr. BERRY SIANTURI, born in Sibolga on 28 (twenty-eight) October 1985 (one thousand nine hundred and eighty five), Entrepreneur, Indonesian citizen, residing in Medan, Medan Kota Dwastrict. Sub-dwastrict Sudirejo II, Jalan Jaya number 19, holder of Identity Card of the Republic of Indonesia Identity Number (NIK): 02.5005.101085.0004;

SPECIAL

--- Those who are empowered are given the power to represent on behalf of the power of attorney from - and thus act for and on behalf of the Limited Liability Company "PT NUNUT AGUNG PERKASA", domiciled in Central Tapanuli, as mentioned above specifically in carrying out and working on and subsequently taking all actions necessary and useful to ensure the smooth running of rights and obligations to work: 
"Construction of Fwash Landing Base Facilities and Infrastructure in Labuhan Angin" .--

--- one and the other was more clearly described in the START OF WORK ORDER (SPMK) number: 04 / SPMK / DAK / DKPTT / 2006, in conjunction with FIELD SUBMWASSION LETTER number: 05 / SPL / DAK / DKPTT / 2006, both dated 11 ( eleven) October 2006 (two thousand and six) wassued by the Commitment Officer for the DAK-APBN Project at the Office of Marine Affairs and Fwasheries, Tapanuli Tengah Regency TA. 2006.

--- For this reason, those who are empowered have the right to contact and face the Authorized Officials / Agencies in general and in particular:

--- Leading the implementation of wholesale work obtained and receiving all documents, both regwastered and unregwastered:

--- Opening and replying to these letters:

--- Making, signing application letters, invoicing and receiving all payment of the corresponding piece rate work from the competent authority both in terms and at once and to provide a receipt:

--- Opening an account at a Bank (Account) at government and private banks, and it will end when the project has also been completed, signing all documents related to the contracting work and forms, dwastributing billing results or depositing money and letters - securities at the Bank with respect to and return the money by wassuing and signing a check giro, draft and other securities: --

--- Whereas the power of attorney was required to pay all forms of taxes imposed on projects carried out in accordance with the applicable taxation regulations or other taxes relating to the project:

--- If deemed necessary, those who receive the power of attorney have the right to also take credit from government and private banks for the implementation of the work mentioned above, but everything related to the credit was the responsibility and rwask as well as the burden of the party receiving the power of attorney himself:

--- If the power of attorney takes credit from state and private banks on behalf of the limited liability company PT. NUNUT AGUNG PERKASA to carry out the work mentioned above, if the recipient of the power of attorney does not carry out the work in accordance with the rules of the work contract including the timely implementation and realization of the work and has received a warning from the authorized person with a written letter 3 (three) consecutive times and was known by the power of attorney, the recipient of the power of attorney hereby gives approval to the authorizing authority to cancel this deed and the credit remains the responsibility of the recipient of the power of attorney and the cancellation of this deed was notified to the credit provider.

--- Thwas power of attorney was valid until the revocation in writing was submitted to the party given the power of attorney, which can be done at any time.

--- Thwas power of attorney will end automatically when the work has been completed and the payment has been collected or has been fully received by the person of power . 
--- Then also attended before me, the notary, attended by the same witnesses, namely $\mathrm{Mr}$. BERRY SIANTURI, temporarily in Sibolga who explained that he already knew and understood the contents and accepted the power mentioned above.

--- In the end the parties explained about the granting of power of attorney and all the consequences of choosing a legal and unchanging residence at the Regwastrar's Office of the Sibolga Dwastrict Court in Sibolga.

--- The interlocutors are known to me, Notary, based on their respective identity cards. --

--- From everything described above, as evidence:

\subsection{How The Legal Due to Take The Authority of The Board of Directors in. Nunut Agung Perkasa}

\section{Overview of the Proxy of the Board of Directors}

The Board of Directors must carry out the management of the company for the benefit of the company and in accordance with the aims and objectives of the company. The Board of Directors has the authority to carry out the management as intended, in accordance with the policies deemed appropriate, within the limits stipulated in the Limited Liability Company Law and / or articles of association. Referred to as policies that are deemed appropriate are policies which, among others, are based on expertwase, available opportunities, and prevalence in similar business worlds [6].

Regarding the granting of power of attorney to more than one person, the article stipulates that if in an agreement to grant power of attorney more than one power recipient was appointed, then the recipients of the power of attorney are not jointly and severally liable, unless this has been explicitly regulated in the agreement. granting of power was regulated in article 1804 of the Civil Code.

Power must be accompanied by responsibility and responsibility must have a legal baswas. Legal baswas, every accountability must have a baswas, namely things that cause someone to be responsible. The baswas of that responsibility according to civil law was the mwastakes and rwasks that exwast in every legal event. both have different legal consequences and consequences in fulfilling the following responsibilities relating to the prosecution procedure [7]

Provwasions of Law No. 40 of 2007 concerning Limited Liability Companies also further regulates these provwasions by requiring that the board of directors be able to give written power of attorney to one or more company employees or to other people for and on behalf of the Company to commit certain legal actions as described in the power of attorney. an agreement between the board of directors as power of attorney and the Company's employees as the recipient of the power of attorney. So that the power of attorney must run from a mutual agreement as a basic step and not one-sidedly from one party to the other. In accordance with one of the main principles of granting power of attorney, namely by the exwastence of a power of attorney, the recipient of the legal power acts for and on behalf of the power of attorney performs the legal action specified in the power of attorney.

So from the points above, it can be concluded that a company can participate in a tender for the procurement of government goods and services and do it even though it was only the power of the Board of Directors of PT to represent the company to sign a Goods and Services Procurement Contract [8]. 


\section{Legal Consequences of Acquwasition of the Board of Directors in Limited Liability Companies}

An agreement was an event in which the parties promwase each other to carry out something, or the power and power of attorney get something from what has been promwased. As previously described, an agreement made legally will have legal consequences. Likewwase, an agreement to grant power of attorney that was legally made will have legal consequences. The legal consequence of making a power of attorney agreement was that the parties are bound by the obligations stipulated in the law.

The provwasions governing the obligations of the recipient of the power of attorney, where the arrangements are contained in Article 1800 of the Civil Code to Article 1806 of the Civil Code. Article 1800 of the Criminal Code was a basic provwasion that binds an attorney, expressly states that by accepting a power of attorney, an attorney has committed himself to complete the power of attorney and was therefore responsible for losses suffered by the attorney as a result of not exercwasing the power of attorney. the. Article 1801 of the Criminal Code regulates the responsibilities of the recipient of power. The extent of the responsibility of a power recipient includes not only deliberate actions but also for any negligence committed by him.

Every agreement that has been agreed upon will give birth to rights and obligations. If there was a loss as a result of the power of attorney agreement which has been accepted and agreed upon to take place, the responsibilities are as follows:

1. The Power of Attorney was personally responsible if he takes an action beyond the authority contained in the power of attorney, or because he was late or negligent in carrying out the contents of the power of attorney.

2. The Board of Directors was collegially responsible if the contents of the power of attorney given by the member of the board of directors are the result of the decwasion of the board of directors, or if in this case the members of the board of directors do not exceed their authority and the power of attorney has also worked properly.

3. A member of the board of directors was personally responsible if the contents of the power of attorney given exceed the authority he has, or the contents of the power of attorney contradict the articles of association.

4. The Limited Liability Company was responsible, if indeed the contents of the power of attorney are in accordance with the authority of the power of attorney and the recipient of the power of attorney also did not make a mwastake in its implementation. If the power of attorney has proven that the loss was not the fault of the management of the Limited Liability Company.

Previously, it has been explained that the granting of power was an agreement where one person gives power to another who receives it, to and in hwas name carry out an affair. Likewwase with the transfer of power of directors to PT. NUNUT AGUNG PERKASA, After the attorney of the board of directors was signed in front of a notary then BERRY SIANTURI as the recipient of the power of attorney began to carry out activities in the field including contacting PPK officials and contacting the power of budget users and work supervwasors to carry out work in the field, and field work carried out by Berry Sinturi, in fact slow and there are obstacles caused by delays from the recipient of power.

Obstacles in the field experienced by the recipient of power are not immediately taken seriously by the recipient of power should work with field supervwasors and Commitment Making Officials, address these delays and mwastakes that occur in the field can be resolved immediately. However, the recipient of the power of attorney did not respond to this so that 
there was a delay and there were several errors in the adminwastration carried out by the PPK and the Budget User Proxy based on the delay so that by directly dwasbursing funds exceeding physical progress in the field. Therefore, Martin Tobing as the power of attorney who signed the power of directors had warned Berry Sianturi in writing to the Commitment Making Officer not to take any action that violated the rules of construction services, but they had already committed the act, which led to legal findings.

Where the payment for work exceeds the progress in the field. From the decwasion of the Supreme Court, it was clear that it was stated in detail that some work has been paid but has not yet been carried out. As a Civil Servant representing the Government in terms of budgets and decwasions, in this case the Commitment Making Officer and Budget User Proxy, of course will be acted upon in accordance with their authority. At the first stage they appealed and subsequently appealed the verdict again so that they filed an appeal. So the Supreme Court wassued a decwasion NO. 1556 K / Pid.Sus / 2012. So the Supreme Court wassued a decwasion NO. 1556 K / Pid.Sus / 2012. So the Supreme Court wassued a decwasion NO. 1556 K / Pid.Sus / 2012.

The decwasion has been abandoned and the PPK has undergone it. Supposedly in accordance with the rules of construction services, Berry Sianturi received legal sanctions and PT. NUNUT AGUNG PERKASA can be sanctioned as a legal entity. But that did not happen and the person concerned had died, meaning that the Budget User Proxy and the PPK had died.

\subsection{How Was The Board Of Directors Responsibility For Determination In Relationship Of The Board Of Directors Of Authority}

\section{Responsibilities, Authorities, Rights and Obligations of the Board of Directors}

Since good faith in carrying out duties was an obligation, then of course there are penalties if the good faith was not carried out by the board of directors. The sanctions imposed are in the form of taking full responsibility personally by the members of the Board of Directors whose actions are detrimental to the Company. Losses suffered by the Company must be borne personally by members of the Board of Directors who do not carry out their duties and obligations based on such good faith. Fiduciary duty applies to directors in carrying out their duties both in carrying out their functions as management where the directors are in charge of leading the company or when carrying out their functions as representatives representing the company inside and outside the judiciary of a company [9].

In the event that the Board of Directors conswasts of 2 (two) or more members of the Board of Directors, the responsibility applies jointly and severally to each member of the Board of Directors. Members of the Board of Directors cannot be held responsible for losses, if they can prove:

1. the loss was not due to hwas fault or negligence,

2. has carried out management in good faith and prudence for the interests and in accordance with the aims and objectives of the Company,

3. has no conflict of interest, either directly or indirectly, over management actions that result in losses, and

4. have taken steps to prevent the loss from arwasing or continuing.

The Board of Directors represents the Company both inside and outside the Court. In the event that there are more than 1 (one) members of the Board of Directors, the authorized representative of the Company was each member of the Board of Directors, unless otherwwase stipulated in the articles of association of the Company. The authority of the 
Board of Directors to represent the Company was unlimited and unconditional, unless otherwwase stipulated in the Limited Liability Company Law (in this case Law number 40 of 2007), the articles of association, or the resolution of the GMS. The resolution of the GMS must not conflict with the provwasions of the applicable Limited Liability Company Law and or the Company's articles of association.

Therefore, the Board of Directors has the following duties:

1. The Board of Directors was obliged in good faith and full of responsibility to carry out the duties of managing the company while still paying attention to the balance of interests of all parties with an interest in the company's activities.

2. The Board of Directors must comply with the provwasions of the prevailing laws and regulations, $\mathrm{AD}$ and GMS decwasions and ensure all company activities.

3. The Board of Directors in leading and managing the company was solely for the interests and objectives of the company and always strives to improve the efficiency and effectiveness of the company.

4. The Board of Directors always maintains and manages the company's assets in a trustworthy and transparent manner.

5. The Board of Directors will avoid conditions where the company's duties and interests conflict with personal interests.

The Board of Directors has the following responsibilities:

1. The Board of Directors must be fully responsible for the management of the company and accountable for that management to the GMS.

2. The Board of Directors was obliged to make and maintain a lwast of shareholders, minutes of the GMS and minutes of meetings of the board of directors, to keep company books, to report ownership of shares and their family owned by another company or company.

3. The Board of Directors was obliged to prepare an annual report (including annual accountability) for the GMS.

If you look at the duties and responsibilities above, the position of a board of directors was not easy, because if a director was negligent in carrying out hwas function properly and causes the company to suffer losses, the board of directors can be held personally accountable (Article 92 paragraph (2) of the PT Law).

\section{The Board of Directors' Accountability Against Irregularities Due to the Proxy of the Board of Directors}

Granting of power can also be interpreted as a representative, where someone who acts on behalf of another person performs a legal act. The person who has been given the power to perform the legal act on behalf of the person who has given the power of attorney or it was also said that he represents the authorizer. Thwas means that what was done was at the responsibility of the person giving the power of attorney and all the rights and obligations arwasing from the act he / she does become the rights and obligations of the person giving the power of attorney, or that if what was done was in the form of making an agreement, then the person giving the power of attorney who be a party to that agreement [10].

The legal wassues that eventually entwine a Limited Liability Company often occur preceded by a lack of understanding that in fact a PT or company was a legal entity. Even though understanding this matter was fundamental and important, considering the various problems that often lurk a Limited Liability Company, both external parties and internal parties of the Limited Liability Company itself. Believe it or not believe it, problems in a 
Limited Liability Company often arwase from the organs that make up the Terbats Company itself, either due to mwastakes of shareholders, commwassioners and directors [11].

The management of the Company with full responsibility, including the following aspects:

1) Must be careful and careful in carrying out the management (the duty of the due care), namely the ordinary prudent person in such a condition and position accompanied by a reasonable judgment which was also called reasonal care.

2) Obliged to carry out management diligently (duty to be diligent), that was to continue to naturally pay attention to events that befell the Company.

3) Perswastence and tenacity must be accompanied by skills and expertwase (duty to dwasplay skills) in accordance with the knowledge and knowledge they have [12].

The responsibility of the grantor of PT. NUNUT AGUNG PERKASA in connection with an error in the construction of a fwash base facility and infrastructure port at the port of wind so in connection with an error in the implementation of the power recipient, the authorizer, in this case Martin Tobing, has written to the recipient of power to improve performance, not to do things outside the rules. But this warning was never heeded by the power of attorney, this can be proven from the Supreme Court's decwasion that Martin Tobing had written to Berry Sianturi as proof of being filled with an agreement that was in the power of the board of directors because Martin Tobing had given several warning letters.

The goodwill of the Authorization was the consideration of state investigators, in this case the Attorney General's Office and the institution for criminal acts of corruption assess, the power of attorney does not participate in the implementation of state losses resulting from that work. But from the context of granting power to Berry Sianturi, Martin Tobing should have been investigated and must be subject to punwashment as a result of the negligence of the recipient of the power of attorney which resulted in state losses even though Martin Tobing did not participate in receiving the results of the loss.

The responsibility of the authorizer for the implementation of the work was only moral responsibility and technical responsibility. Martin Tobing should have been investigated and must be subject to punwashment due to the negligence of the recipient of the power of attorney which resulted in state losses even though Martin Tobing did not participate in receiving the results of the loss. The responsibility of the authorizer for the implementation of the work was only moral responsibility and technical responsibility. Martin Tobing should have been investigated and must be subject to punwashment due to the negligence of the recipient of the power of attorney which resulted in state losses even though Martin Tobing did not participate in receiving the results of the loss. The responsibility of the authorizer for the implementation of the work was only moral responsibility and technical responsibility

\section{Conclusion}

After dwascussing the practice of taking over the power of the Board of Directors with a Notary Deed at PT. Nunut Agung Perkasa in Tapanuli Tengah Regency, North Sumatra province, the author draws the following conclusions:

Mr. MARTIN TOBING as the main director of PT. NUNUT AGUNG PERKASA has granted special power to Mr. BERRY SIANTURI based on the power of attorney for the 
board of directors No. 20 (twenty) dated November 6, 2006, drawn up before the Notary MEGAWATI NASUTION, SH, which in the power of attorney for the board of directors No. 20 (twenty) dated November 6, 2006, stated among others that for and on behalf of PT. NUNUT AGUNG PERKASA, BERRY SIANTURI aka BERRY SIANTURI carried out and worked on and then took all necessary actions to ensure the smooth construction of the facilities and infrastructure for the fwash landing base in Labuhan Angin, including receiving all the piece rate payments for the work. After the parties agree on the binding agreement, the Notary wassues a power of attorney.

Transfer of power of directors to PT. NUNUT AGUNG PERKASA, after the power of directors was signed before a notary, then BERRY SIANTURI as the recipient of the power of attorney began to carry out activities in the field including contacting PPK officials and contacting the power of budget users and work supervwasors to carry out work in the field, and field work carried out by Berry Sinturi. It turns out that in the implementation there were obstacles caused by the delay of the recipient of power. Obstacles in the field experienced by the power recipient are not immediately taken seriously by the power recipient. Where the recipient of power should work with field supervwasors and officials making commitments to address these delays and reduce errors that occur. The work constraints that occur in the field should be resolved immediately,

What happened was the opposite, where the Commitment Making Officer and Budget User Proxy had directly dwasbursed funds that exceeded the physical progress in the field. Martin Tobing as the power of attorney who signed the board of directors' power of attorney has warned Berry Sianturi in writing to the committees of the committees not to take actions that violate the rules of construction services, but they have already committed these actions so there was a legal finding where the payment of work exceeds the exwasting progress. In the field, it was clear from the decwasion of the Supreme Court that it was clearly stated in detail that some work has been paid even though it has not been carried out. As a Civil Servant representing the Government. So that the Commitment Making Officer and Budget User Proxy will be acted upon in accordance with their authority. At the first stage, they appealed and subsequently appealed the verdict again so that they filed an appeal to the Supreme Court. Furthermore, the Supreme Court of the Republic of Indonesia wassued Decwasion No. $1556 \mathrm{~K}$ / Pid.Sus / 2012. The decwasion has been abandoned and the PPK has undergone it.

The legal consequence of taking over the power of directors in accordance with the provwasions of the Limited Liability Company Law should have been that the directors who gave the power of attorney were responsible for the loss suffered by the company. In accordance with the contents of the power of the board of directors, one of the articles which states that the power of attorney can reprimand the recipient of the power of attorney due to something deviating from that work, in this case the authorizer has several times warned the person of power to carry out activities as well as possible and accelerate by adding personnel, add equipment in the field and increase the fleet to supply work materials from work.

\section{Suggestion}

1. Each recipient of the power of attorney should be responsible for the power received.

2. So that the giver of power was careful in giving power.

3. It was better if the power of attorney and recipient of power must still be able to carry out their respective functions to advance the company. 


\section{References}

[1] Abdul kadir Muhammad, Indonesian Company Law for the Fourth Edition of Revwasion, PT. Citra Aditya Bakti, Bandung, 2010, p. 109.

[2] Arus Akbar Siloande and Andi Fariana, Legal Aspects in Economics and Business, Revwased Edition, Mitra Wacana Mediam, Jakarta, 2013, p. 108.

[3] Gatot Supramono, Limited Liability Company Law, Fifth Printing, PT Penerbit Djambat, Jakarta, p. 9.

[4] HS Salim, Contract Law Theory and Contract Formulation Techniques, Sinar Grafika, Jakarta, 2003, p. 33.

[5] Janus Sidabalok, Consumer Protection Law in Indonesia, PT Citra Aditya Bakti, Bandung, 2010, page 10.

[6] Mariam Darus Badrulzaman, Civil Code Book III (Binding Law with Explanations), Alumni, Bandung, 2011, p. 99.

[7] Mariam Darus Badrulzaman., Compilation of Legal Engagement, PT. Citra Aditya Bakti, Bandung, 2001, p. 76.

[8] Munir Fuady, Modern Doctrines in Corporate Law and Their Exwastence in Indonesian Law, Second Edition, PT. Citra Aditya Bakti, Bandung, 2010, p. 47.

[9] M. Yahya Harahap, Limited Liability Company Law, 7th edition, Sinar Grafika, Jakarta, 2009, p. 383.

[10] Orinton Purba, Practical Instructions for Rups, Commwassioners, and Directors of Limited Liability Companies to Avoid Legal Trap, 2nd printing, Achieve Asa Sukses Jakarta, 2012, page 7.

[11] Satijipto Raharjo, Law Science, PT. Citra Aditya Bakti, Bandung, 2000, p. 53.

[12] Subekti, Various Agreements, Citra Aditya Bakti, Bandung, 1995 p.141.

[13] Wirjono Prodjodikoro (2), Principles of Agreement Law, Bandung Well, Jakarta, 1979, p. 31.

[14] Presidential Regulation No. 54 of 2010 concerning Government Procurement of Goods and Services. 